\title{
MORBIDITY PROFILE OF UNDER FIVE CHILDREN RESIDING IN BARBOTE VILLAGE DEVELOPMENT COMMITTEE OF ILAM DISTRICT OF EASTERN NEPAL
}

\author{
Sharma $K R^{1^{*}}$, Dawadi $S^{2}$, Upadhaya $P^{3}$, Khanal $V K^{4}$, Singh $S B^{5}$
}

\begin{abstract}
Affiliation
1. Assistant Professor, school of Public Health \& Community Medicine, B. P. Koirala Institute of Health Sciences, Dharan

2. Intern, B. P. Koirala Institute of Health Sciences, Dharan

3. Junior Resident, school of Public Health \& Community Medicine, B. P. Koirala Institute of Health Sciences, Dharan

4. Associate Professor, School of Public Health \& Community Medicine, B. P. Koirala Institute of Health Sciences, Dharan

5. Additional Professor, School of Public Health \& Community Medicine, B. P. Koirala Institute of Health Sciences, Dharan
\end{abstract}

\section{ARTICLE INFO}

\section{Article History}

Received : 7 September, 2018

Accepted : 16 December, 2018

Published : 31 December, 2018

(c) Authors retain copyright and grant the journal right of first publication with the work simultaneously licensed under Creative Commons Attribution License CC - BY 4.0 that allows others to share the work with an acknowledgment of the work's authorship and initial publication in this journal.

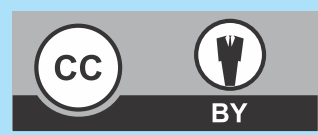

ORA 89

DOI: $\underline{10.3126 / \text { bjhs.v3i3.22189 }}$

\author{
* Corresponding Author \\ Dr. Khem Raj Sharma \\ Assistant Professor \\ School of Public Health \& Community Medicine \\ B. P. Koirala Institute of Health Sciences, Dharan \\ Email: khem.sharma@bpkihs.edu \\ ORCID ID: https://orcid.org/0000-0001-6979-1742
}

\section{Citation}

Sharma KR, Dawadi S, Upadhaya P, Khanal VK, Singh SB. Morbidity Profile of Under Five Children Residing in Barbote Village Development Committee of Ilam District of Eastern Nepal. BJHS 2018;3(3)7: 554-559

\section{ABSTRACT}

\section{Introduction}

In 2017, the under-five mortality rate in low-income countries was 69 deaths per 1000 live births-around 14 times the average rate in high-income countries. Children constitute a vulnerable group and the first five years can be considered as a transition phase from the mother's womb to a social platform. Morbidity status of very young children is considered to be an important index of the health status of the community.

However, studies done to assess the morbidity profile of Children in rural Nepal are few, and the children's health status is largely unknown. The information collected through Health Management Information System (HMIS) of Nepal Government mainly represent the population that accessed the services but do not represent the population that utilized private clinics/hospitals or did not access it at all.

\section{Objective}

This study was conducted to assess the morbidity status of under-five children and its associated factors in Barbote Village Development Committee (VDC) of Ilam district of eastern Nepal.

\section{Methodology}

A community based cross-sectional study was conducted among all the eligible under five children of Barbote VDC of Ilam District for two weeks from 16-30 March, 2016. Face-to-face interviews were conducted with the legal guardian/ caretaker of the children with pre-tested, semi-structured questionnaire. Calibrated \& validated equipment were used for simple biophysical measurements. Odds Ratio (OR) with confidence limit was calculated to examine the strength of association between the variables with the probability of significance set at 95\% of Confidence interval (Cl).Ethical permission was taken from the Institutional Review Committee (IRC) of BP Koirala Institute of Health Sciences, Dharan.

\section{Results}

Of the total 406 under-five children studied, 35.5\% complained of illness such as acute respiratory infection, diarrhea and fever within the past two weeks. Regression analysis by the backward conditional method disclosed the fact that children of households with low socioeconomic status and those using biomass fuel for cooking were significantly associated with presence of illness.

\section{Conclusion}

More than one-third of the under-five children in BarboteVDC of eastern Nepal were found to be ill mostly due to preventable causes. Factors significantly associated with the presence of illness included the use of biomass fuel and low socio-economic status.

\section{KEY WORDS}

Child, Disease, Morbidity 


\section{INTRODUCTION}

In 2017, the under-five mortality rate in low-income countries was 69 deaths per 1000 live births-around 14 times the average rate in high-income countries. ${ }^{1}$ Children constitute a vulnerable group and are the leaders of the future. So it becomes important for each nation to safeguard and promote the health of its children. Morbidity status of children under five is an important index of the health status of a community.

The health status of children in Nepal has improved over the last decade with the attainment of MDG targets. ${ }^{2}$ However, developing countries like Nepal still have a long hurdle to cross to promote the health status of its future generations. With the incorporation of child health programs in the national health system, the under-five mortality has been reduced to $33.7 / 1000$ live births, which is still very much high. ${ }^{3}$

First five years of life is a transition phase for the child from the mother's womb to the social platform. It is a very crucial phase as physical, psychological and social growth and development are intensively ongoing in this period. This requires adequate amounts of quality nutrition and various other resources. Lack in any one resource could result in grave consequences with irreversible damage that could compromise their potential in later life. ${ }^{4}$

Nepal Government routinely collects data on Under-five children attending the Government Health Facilities through the Health Management Information System and publishes it in the form of Annual Report. ${ }^{5}$ However, this report is incomplete as it misses those children attending the private sector or in the community and does not give a complete picture of the situation. In the present day world, accurate data is required for the implementation of measures for management of health conditions. Studies done in the community give a clear picture of the real situation to aid in prioritizing the application of methods for prevention \& control. So, this study was conducted to assess the morbidity status of under-five children and its associated factors in Barbote Village Development Committee (VDC) of Ilam district of eastern Nepal.

\section{METHODOLOGY}

A community based cross-sectional study was conducted for two weeks duration, from16 to 30 March 2016, among under five year old children in all the nine wards of Barbote VDC of Ilam district with an under-five population of 416 . This was a census study where a total of 406 children were enrolled from all wards covering $97.6 \%$ of the under-five population of Barbote VDC. ${ }^{6}$ The remaining children were either unavailable even after 3 visits, or did not give consent for the study.

In each eligible household, the nature and purpose of study was clearly explained and an informed written consent was obtained. Face-to-face interviews were conducted with the adult legal guardian/caretaker of the child from the eligible households with a pre-tested semi-structured questionnaire. The data collection tool consisted of socio-demographic section, birthing and feeding practices of the child, housing environment and clinical profile. Calibrated and validated equipment were used for simple biophysical measurements like height and weight and other parameters were assessed using standardized protocols. All children below 60 months were included except those who did not provide consent.

\section{Operational definitions}

Illness was defined as a period of sickness affecting the body at the time of visit or within 2 weeks prior to it, based on the Community Based Integrated Management of Neonatal and Childhood Illness (IMNCI) guidelines of Nepal. ${ }^{7}$ IMNCI primarily includes Acute Respiratory Infection (ARI), Diarrhoea, Fever and Nutritional status assessment. Overcrowding was defined as less than 70 square feet of floor space area per person in the household. Floor space area refers to total floor space area of all the sleeping room in house divided by the number of family members. ${ }^{8}$ Pucca houses are made from high quality materials, i.e. bricks, cement, concrete, including roof, walls and floor while katcha houses are made from mud and thatch or other low quality materials. Semi-pucca houses are made from a combination of the above types. ${ }^{9}$ This study considered family size, overcrowding, cross ventilation, type of house, natural lighting, and type of cooking fuel as proxy measures for housing conditions. Those households with per-capita/day less than $1.90 \$$ was considered as being below poverty line. ${ }^{10}$

Bivariate analysis with chi-square tests were done to find the statistical significance between two or more categorical variables. Odds Ratio (OR) with confidence limit was calculated to examine strength of association between the variables. Logistic regression analysis by the backward conditional method was performed for all independent variables whose probability was less than $20 \%$ in the bivariate analysis. This was done to identify associated factors for morbidity in under five children with the probability of significance set at $95 \%$ of confidence interval (CI). Ethical permission was taken from the Institutional Review Committee (IRC) of B. P. Koirala Institute of Health Sciences. Permission was also taken from the local authority of Barbote VDC. The children found to be ill during the study were managed at the local health centre.

\section{RESULTS}

The distribution of 406 under five children in the various wards of Barbote VDC is depicted in figure 1.

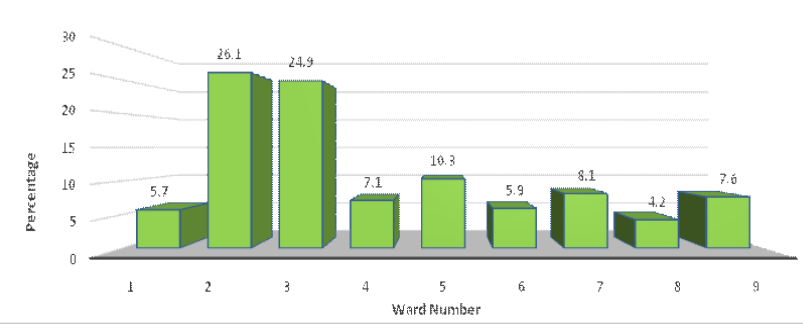

Figure 1: Ward wise distribution of participants of Barbote VDC, Ilam $(n=406)$

Majority (81\%) of the participants were mothers of the eligible children. Infants constituted $14 \%$ of the study population and sex distribution was almost equal. They were mostly of Janajati (48.5\%) and Brahmin/Chettri (43.1\%) ethnicity and $54.2 \%$ lived in a nuclear family. Almost $78 \%$ of the families of under-five children were living above poverty line in Barbote VDC with $46.8 \%$ in the lower middle class category of the modified kuppuswamy socioeconomic scale (Table 1 ). 


\begin{tabular}{|c|c|c|c|}
\hline Characteristics & Categories & Frequency & Percentage \\
\hline \multirow{3}{*}{ Age of child } & Below 1 year & 57 & 14.0 \\
\hline & 12 to 23 months & 75 & 18.5 \\
\hline & 2 years or above & 274 & 67.5 \\
\hline \multirow{2}{*}{ Sex } & Female & 204 & 50.2 \\
\hline & Male & 202 & 49.8 \\
\hline \multirow{3}{*}{ Ethnicity } & Janajati & 197 & 48.5 \\
\hline & Brahmin/Chettri & 175 & 43.1 \\
\hline & Others(Madhesi, Dalit) & 34 & 8.4 \\
\hline \multirow{3}{*}{ Religion } & Hindu & 296 & 72.9 \\
\hline & Kirat & 85 & 20.9 \\
\hline & $\begin{array}{c}\text { Others(Buddhist,Christian } \\
\text { \&Muslim) }\end{array}$ & 25 & 6.2 \\
\hline \multirow{2}{*}{ Type of Family } & Nuclear & 220 & 54.2 \\
\hline & Joint & 186 & 45.8 \\
\hline \multirow{2}{*}{ Poverty Status } & $\begin{array}{c}\text { Below Poverty line } \\
\text { (<1.9\$/day) }\end{array}$ & 90 & 22.2 \\
\hline & $\begin{array}{c}\text { Above Poverty line } \\
\text { ( } \geq 1.9 \$ / \text { day })\end{array}$ & 316 & 77.8 \\
\hline \multirow{5}{*}{$\begin{array}{l}\text { Kuppuswamy } \\
\text { Socio- } \\
\text { economic } \\
\text { Status Scale }\end{array}$} & Lower Class & 5 & 1.3 \\
\hline & Upper Lower Class & 76 & 18.7 \\
\hline & Lower Middle Class & 190 & 46.8 \\
\hline & Upper Middle Class & 132 & 32.5 \\
\hline & Upper Class & 3 & 0.7 \\
\hline
\end{tabular}

Nearly $81.5 \%$ of the mothers of under-five children were 20 30 years of age, almost $40 \%$ had completed secondary level education and only $5.4 \%$ were illiterate (Table 2 ) of the total 406 children, $88.4 \%$ delivered in Hospital, $80 \%$ had undergone normal delivery and $4.7 \%$ were pre-term deliveries. Only $4.4 \%$ of the children had low birth weight, while 4.7 were overweight at birth. Over $95 \%$ of the mothers had fed colostrum to the child while only $53.4 \%$ had undertaken exclusive breast feeding practices. Regarding immunisation status, $99.8 \%$ and $88.2 \%$ had received BCG and Measles respectively. Of the total 274 children of 2-5 years age group, all (100\%) had been fully immunized.

\begin{tabular}{|c|c|c|c|}
\hline Characteristics & Categories & Frequency & Percentage \\
\hline \multirow{3}{*}{ Age of mother } & Below 20 years & 26 & 6.4 \\
\hline & 20 to 30 years & 331 & 81.5 \\
\hline & Above 30 years & 49 & 12.1 \\
\hline \multirow{6}{*}{ Mothers education } & Illiterate & 22 & 5.4 \\
\hline & Primary & 24 & 5.9 \\
\hline & Lower Secondary & 71 & 17.5 \\
\hline & Secondary & 162 & 39.9 \\
\hline & Higher Secondary & 102 & 25.1 \\
\hline & Bachelors and above & 25 & 6.2 \\
\hline \multirow{3}{*}{ Gestational age } & Term & 370 & 91.1 \\
\hline & Pre-term & 19 & 4.7 \\
\hline & Post-term & 17 & 4.2 \\
\hline \multirow{2}{*}{ Delivery institution } & Hospital & 359 & 88.4 \\
\hline & Home & 47 & 11.6 \\
\hline \multirow{2}{*}{ Mode of delivery } & Normal & 325 & 80.0 \\
\hline & Cesarean section & 81 & 20.0 \\
\hline \multirow{3}{*}{ Birth weight } & Low birth weight & 18 & 4.4 \\
\hline & Normal & 369 & 90.9 \\
\hline & Overweight (>4kg) & 19 & 4.7 \\
\hline \multirow{2}{*}{ Child fed colostrum } & Yes & 387 & 95.3 \\
\hline & No & 19 & 4.7 \\
\hline \multirow{2}{*}{ Exclusive breast feeding } & Yes & 217 & 53.4 \\
\hline & No & 189 & 46.6 \\
\hline \multirow{2}{*}{ Immunization } & Fully Immunized & 358 & 88.2 \\
\hline & Not fully immunized & 48 & 11.8 \\
\hline \multirow{2}{*}{ BCG vaccination } & Yes & 405 & 99.8 \\
\hline & No & 1 & 0.2 \\
\hline
\end{tabular}

A good proportion of the study subjects lived in a Katcha type of house (44.6\%) and overcrowding was present in around $20 \%$ of the households (Table 3 ). Almost all (>98\%) households boiled water for consumption and around 54\% still used Biomass fuel for cooking. Distance of latrine from the water-source was less than 15 meters in $62.3 \%$ of the households, while majority of the households (88.9\%) had a water-seal type of latrine. At least one cigarette smoker was present in $13.5 \%$ of the households visited.

\begin{tabular}{|c|c|c|c|}
\hline Characteristics & Categories & Frequency & Percentage \\
\hline \multirow{3}{*}{ Type of house } & Katcha & 181 & 44.6 \\
\hline & Semi-Pucca & 159 & 39.2 \\
\hline & Pucca & 66 & 16.2 \\
\hline \multirow{2}{*}{ Overcrowding } & No & 323 & 79.6 \\
\hline & Yes & 83 & 20.4 \\
\hline \multirow{2}{*}{$\begin{array}{l}\text { Boiling water for } \\
\text { drinking }\end{array}$} & Yes & 397 & 97.8 \\
\hline & No & 9 & 2.2 \\
\hline \multirow{2}{*}{ Cooking fuel } & Biomass & 220 & 54.2 \\
\hline & Others & 186 & 45.8 \\
\hline \multirow{3}{*}{ Type of latrine } & Water seal & 361 & 88.9 \\
\hline & Pit & 43 & 10.6 \\
\hline & Absent & 2 & 0.5 \\
\hline \multirow{2}{*}{$\begin{array}{l}\text { Distance of latrine } \\
\text { from water source }\end{array}$} & $\begin{array}{l}\text { Less than } \\
15 \text { meters }\end{array}$ & 253 & 62.3 \\
\hline & $\begin{array}{c}15 \text { meters } \\
\text { or more }\end{array}$ & 153 & 37.7 \\
\hline \multirow[t]{2}{*}{$\begin{array}{l}\text { Cigarette smoker in } \\
\text { the house }\end{array}$} & Yes & 55 & 13.5 \\
\hline & No & 351 & 86.5 \\
\hline
\end{tabular}

A total of $35.5 \%$ of the under-five children gave a history of illness within the past two weeks with $23.7 \%$ complaining of ARI and 5.2\% had diarrhoea. (Table 4)

\begin{tabular}{|c|c|c|c|}
\hline Characteristics & Categories & Frequency & Percentage \\
\hline \multirow[t]{2}{*}{ Illness present } & Yes & 144 & 35.5 \\
\hline & No & 262 & 64.5 \\
\hline \multirow[t]{5}{*}{ Type of Illness } & $\begin{array}{c}\text { Acute } \\
\text { respiratory } \\
\text { illness }\end{array}$ & 96 & 23.7 \\
\hline & Diarrhoea & 21 & 5.2 \\
\hline & Fever & 22 & 5.4 \\
\hline & Others & 5 & 1.2 \\
\hline & No illness & 262 & 64.5 \\
\hline \multirow{3}{*}{$\begin{array}{l}\text { Mid Upper Arm } \\
\text { Circumference } \\
\text { (MUAC) }(\mathrm{cm})\end{array}$} & $<12.5$ & 10 & 2.5 \\
\hline & $12.5-13.5$ & 48 & 11.8 \\
\hline & $\begin{array}{l}13.5 \text { and } \\
\text { above }\end{array}$ & 348 & 85.7 \\
\hline
\end{tabular}

Bivariate analysis disclosed that under five children aged less than 3 years, belonging to Janajati ethnicity, low socioeconomic status and use of Biomass fuel for cooking were significantly associated with presence of illness (Table 5). However, after adjusting for other variables, Low socioeconomic status [aOR=2.1: $95 \% \mathrm{Cl}(1.32-3.34) ; \mathrm{p}=0.002$ ] and use of Biomass fuel for cooking [aOR=1.6: $95 \% \mathrm{Cl}(1.03-2.37)$; $p=0.036]$ were found to be significantly associated with the presence of illness in the under-five children (Table 6). 
Table 5: Bivariate Analysis

\begin{tabular}{|c|c|c|c|c|c|c|c|c|}
\hline \multirow{2}{*}{ Characteristic } & \multirow{2}{*}{ Category } & \multicolumn{2}{|c|}{ Illness (\%) } & \multirow{2}{*}{$\begin{array}{c}\text { Total } \\
(n=406)\end{array}$} & \multirow{2}{*}{ OR } & \multicolumn{2}{|c|}{$95 \% \mathrm{Cl}$} & \multirow{2}{*}{ Significance } \\
\hline & & Present & Absent & & & Lower & Upper & \\
\hline \multirow{2}{*}{ Age Groups } & 3years \& above & 30.2 & 69.8 & 189 & & & & \\
\hline & $<3$ years & 40.1 & 59.9 & 217 & 1.55 & 1.03 & 2.34 & 0.037 \\
\hline \multirow{2}{*}{ Sex } & Male & 38.1 & 61.9 & 202 & & & & \\
\hline & Female & 32.8 & 67.2 & 204 & 1.26 & 0.84 & 1.89 & 0.267 \\
\hline \multirow{2}{*}{ Ethnicity } & Others & 40.2 & 59.8 & 209 & & & & \\
\hline & Janajati & 30.5 & 69.5 & 197 & 1.53 & 1.02 & 2.3 & 0.04 \\
\hline \multirow{2}{*}{$\begin{array}{c}\text { Kuppuswamy SES } \\
\text { Scale }\end{array}$} & Middle/Upper & 24.4 & 75.6 & 135 & & & & \\
\hline & Lower & 41.0 & 59 & 271 & 2.1 & 1.35 & 3.4 & 0.001 \\
\hline \multirow{2}{*}{ Cooking Fuel } & Others & 41.4 & 58.6 & 186 & & & & \\
\hline & Biomass & 30.5 & 69.5 & 220 & 1.61 & 1.07 & 2.43 & 0.022 \\
\hline \multirow{2}{*}{ Overcrowding } & Absent & 35.6 & 64.4 & 323 & & & & \\
\hline & Present & 34.9 & 65.1 & 83 & 0.97 & 0.59 & 1.61 & 0.9 \\
\hline \multirow{2}{*}{$\begin{array}{c}\text { Cigarette } \\
\text { smokerathome }\end{array}$} & Absent & 34.8 & 65.2 & 351 & & & & \\
\hline & Present & 40.0 & 60.0 & 55 & 1.25 & 0.69 & 2.24 & 0.45 \\
\hline \multirow{2}{*}{$\begin{array}{l}\text { Mothers } \\
\text { education }\end{array}$} & Illiterate & 22.7 & 77.3 & 22 & & & & \\
\hline & Literate & 36.2 & 63.8 & 384 & 0.52 & 0.187 & 1.4 & 0.19 \\
\hline
\end{tabular}

Table 6: Logistic Regression Analysis

\begin{tabular}{|c|c|c|c|c|c|}
\hline \multirow{2}{*}{ Characteristics } & \multirow{2}{*}{ Category } & \multirow{2}{*}{$\begin{array}{c}\text { Adjusted OR } \\
\text { (aOR) }\end{array}$} & \multicolumn{2}{|c|}{$95 \% \mathrm{Cl}$} & \multirow{2}{*}{$\begin{array}{l}\text { Significanc } \\
\text { e (p-value) }\end{array}$} \\
\hline & & & Lower & Upper & \\
\hline \multirow{2}{*}{$\begin{array}{c}\text { Kuppuswamy } \\
\text { Socioeconomic } \\
\text { status }\end{array}$} & Middle/Upper & & & & \\
\hline & Lower & 2.1 & 1.32 & 3.34 & 0.002 \\
\hline \multirow{2}{*}{ Cooking Fuel } & Others & & & & \\
\hline & Biomass & 1.6 & 1.03 & 2.37 & 0.036 \\
\hline
\end{tabular}

Goodness of fit: Chi-square $=1.262, \mathrm{df}=6, \mathrm{p}=0.974$

Variable(s) entered on step 1: Age, Ethnicity, Kuppuswamy Socio-economic status, Cooking fuel and Mothers Education Level.

\section{DISCUSSION}

This study found illness prevalent in $35.5 \%$ of the under-five children in Barbote Village Development Committee (VDC) of Ilam District with $23.7 \%$ suffering from ARI. This is similar to the findings of a study done in Gorkha which showed a prevalence of acute respiratory infection (ARI) in $21.5 \%$. Annual Report 2015/16 of Department of Health Services, also reported ARI among $23 \%$ of under-5 year children in Nepal. ${ }^{5}$ Similarly, a study done in Ethiopia also found similar prevalence of ARI. ${ }^{12}$ This brings us to an inference that morbidity and mortality in under five children has decreased significantly in the recent years. However, the reported prevalence is still high, as these are preventable conditions that impart a large burden on the already overstretched health system of a developing country like Nepal.

On bivariate analysis, children less than 3 years were 1.5 times more likely to fall ill than older children [OR: $1.55 ; \mathrm{Cl}$
(1.03-2.34)]. Similar findings have been seen from studies around the world, as younger children are more susceptible to various pathogens. ${ }^{13-15}$ However, a hospital based study done in Kathmandu, Nepal has reported that older children are more prone to ARI than younger ones. ${ }^{16}$ One possible reason for this could be the fact that older children voice their signs and symptoms more clearly than young ones and thus have more chances of visiting hospitals, resulting in higher use of hospital indoor/outdoor services. However, this finding did not remain significant after adjusting for other variables in the present study.

Lower levels of education of the mother has also been implicated in morbidity of under-five children in various studies. ${ }^{14,15}$ However this study did not find any significant association.

In this study, based on the classification of Nepal Demographic and Health Survey $2001,{ }^{17}$ children of hill Janajati ethnicity were found to fall ill 1.5 times more compared to other ethnicities [OR: 1.53; $\mathrm{Cl}$ (1.02-2.3)]. Social determinants, habits, traditions and customs increase the risk of infection among Janajati children, since these families tend to be larger and live in more crowded conditions. The National Legal Code (Muluki Ain) proclaimed in the period of 
autocratic Rana rulein 1854 AD categorized them as nonenslavable matwali (liquor drinkers) based on their fondness for alcohol. ${ }^{18}$ Similarly, a study on transmission of tuberculosis infection to under-five children in household contact in Sunsari District reported that hill janajati children under five years of age were 2.5 times more likely to be Mantoux test positive - a proxy measure of transmission of Tuberculosis infection. ${ }^{19}$ Data from the NDHS 2001 show that access to and use of a range of health and family planning services is consistently lower among Dalit and most Janajati women. ${ }^{17}$ Literature also suggests that variations in individual health service utilization behavior is culturally conditioned. ${ }^{20}$ These factors could pose additional risks for the hill janajati children in comparison to other ethnicity children. However, this significance was lost in the regression analysis.

The chances of disease and ill health are more in lower socioeconomic status (SES) population. Similarly in this study, using the modified Kuppuswamy socio-economic scale to assess this parameter revealed the fact that being in the low SES predisposed the child 2.1 times more for illness compared to the middle or upper SES [adjusted OR: $2.1 ; \mathrm{Cl}$ (1.35-3.4)]. This was significantly associated even after adjusting for other variables in the regression analysis. Similar results were seen in studies done in India ${ }^{21}$ and Brazil. $^{22}$ The ability to afford and provide for resources in a household is one of the determinants of the health status of its members. So low SES households cannot afford to provide for quality nutritional food and health care in the required amount for its members that predisposes them to illness. The three delays (seeking care, reaching care and receiving care) are accentuated due to the lack of resources of the low SES population.

This study found $54.2 \%$ of the households of Barbote VDC using Biomass fuel for cooking. Under-five children in those households were found to be 1.61 times at more odds of developing illness than children in households that used other forms of fuel. This remained statistically significant even after adjusting for other variables [adjusted OR: 1.61; $\mathrm{Cl}$ (1.07-2.43)]. A study done in Dhading District of Nepal found $87 \%$ of households using solid biomass as a primary source of fuel resulting in a total of 1284 Disability Adjusted Life Years (DALY) lost due to ARI and pneumonia and about 50 percent of it was attributed to indoor air pollution in the household. ${ }^{23}$ Indoor air pollution due to biomass fuel is a major risk factor for morbidity as previously shown by various studies. ${ }^{12,14,15,16,21}$ Use of alternative cleaner fuels, education about effects of smoke on children in the household, and procedures to ventilate the room could be some of the few measures to reduce its health effects on children.

\section{CONCLUSION}

Although, morbidity and mortality in under five children has decreased significantly in the recent years, the reported prevalence of $35.5 \%$ is still high, as these are preventable conditions that imparts a large burden on the already over stretched health system of a developing country like Nepal. Low Socio-economic status and use of Biomass fuel for cooking were found to be significantly associated with the presence of illness in under five children of Barbote VDC, llam.

\section{RECOMMENDATIONS}

These preventable conditions, have simple and effective solutions. Behavioral Change Communication (BCC) activities should be employed to reach the population, far and wide, on the alternatives to biomass fuels. Use of cleaner fuels should be advocated at the national level along with adequate counselling of the guardians during the health post visit regarding biomass use and effects of indoor air pollution. Child to parent advocacy, a new concept of inculcating habits and behaviors, should be practiced through schools by inclusion of these subject matters in the curriculum with practical demonstrations.

\section{LIMITATION OF THE STUDY}

Additional measures like routine lab investigations of the ill children to supplement the study tools would have provided a more comprehensive picture of the overall health of the children, but was not possible due to limitation of resources.

\section{ACKNOWLEDGEMENTS}

The authors would like to thank the participants of Barbote VDC, Ilam for their hospitality and keen participation in this research. The authors are also grateful to School of Public Health \& Community Medicine, BPKIHS for providing an opportunity to conduct the research. Last but not the least, the authors are indebted to Barbote VDC office for their support through out the research.

\section{CONFLICT OF INTEREST}

The authors would like to declare no conflict of interest.

\section{Financial disclosure}

No financial support was obtained for this research. 


\section{REFERENCES}

1. World Health Organization. Global Health Observatory (GHO) data: under-five mortality-2017 accessed on 28/10/2018 and available at http://www.who.int/gho/child_health/mortality/mortality_under_ five_text/en/

2. National Planning Commission. Nepal and the Millennium Development Goals Final Status Report 2000-2015. published on December 2016 accessed on 28/10/2018 and available from https://www.npc.gov.np/images/category/MDG-Status-Report2016_.pdf

3. The World Bank. Mortality rate, under-5 (per 1,000 live births) 2017 available at https://data.worldbank.org/indicator/ SH.DYN.MORT?! ocations=NPand accessed on29/10/2018

4. Shinde M, Joshi A, Trivedi A. Morbidity profile of preschool children in rural area of central Madhya Pradesh. International Journal of Community Medicine and Public Health, 2015. 2(3) 298-301.

5. Ministry of Health, Nepal. Department of Health Services, Annual Report 2015/16. accessed on 21/10/2018 and available at http: //dohs.gov.np/wp-content/uploads/2017/06/DoHS_Annual_ Report_2072_73.pdf

6. Govt. of Nepal, CBS: National Population and Housing Census 2011accessed on 29/10/2018 and available athttp://cbs.gov. $\mathrm{np} /$ image/data/Population/VDC-Municipality\% 20in\% 20 detail/03\% 201 llam_VDCLevelReport.pdf

7. Ministry of Health and Population, Nepal. Child Health ServicesCB-IMNCl available at http://www.mohp.gov.np/eng/program/childhealth-services/cbimnci and accessed on 29/10/2018.

8. Park K. Park's Text book of Preventive and Social Medicine. 24th edition. Jabalpur: M/s Banarshidas Bhanot; 2009. 512p. ISBN: 97893822190579382219056.

9. Agrawal S. Effect of Living Arrangement on the Health Status of Elderly in India. Asian Population Studies. 2012; 8(1): 87-101. doi: 10.1080/17441730.2012.646842

10. Asian Development Bank. Poverty in Nepal 2018available at https:// www.adb.org/countries/nepal/poverty and accessed on 29/10/2018.

11. Maharjan PL, Sharma Y. Prevalence and Determinants of Acute Respiratory Infection among Children under Age Five in Gorkha Municipality, Gorkha. Glob J Pharmaceu Sci 2(3):555588 (2017). DOI: 10.19080/GJPPS.2017.02.555588.
12. Sanbata H, Asfaw A, Kumie A. Association of biomass fuel use with acute respiratory infections among under- five children in a slum urban of Addis Ababa,Ethiopia. BMC Public Health 2014, 14:1122. doi:10.1186/1471-2458-14-1122.

13. Khalek EMA, Salam DMA. Acute respiratory tract infections in children under 5 years of age in Upper Egypt. Int J Community Med Public Health. 2016 May;3(5):1161-1166.

14. Ujunwa FA, Ezeonu CT. Risk Factors for Acute Respiratory Tract Infections inUnder-five Children in Enugu Southeast Nigeria. Ann Med Health Sci Res 2014;4:95-9.

15. Hasan MM, Richardson A. How sustainable household environment and knowledge of healthy practices relate to childhood morbidity in South Asia: analysis of survey data from Bangladesh, Nepal and Pakistan. BMJ Open 2017;7:e015019. doi:10.1136/bmjopen-2016-015019.

16. Karki S, Fitzpatrick AL, Shrestha S. Risk Factors for Pneumonia in Children under 5 Years in a Teaching Hospital in Nepal. Kathmandu Univ Med J2014;48(4):247-52.

17. Ministry of Health. Nepal Demographic and Health Survey 2001 accessed on 5/6/2018 and available at https://dhsprogram. com/ pubs/pdf/fr132/fr132.pdf.

18. Bennett L, Dahal DR, Govindasamy P. Caste, Ethnic and Regional Identity in Nepal - Further Analysis of the 2006 Nepal Demographic and Health Survey available at http://pdf.usaid.gov/ pdf_docs/ Pnadm638. pdf, accessed on 19/10/2018.

19. Sharma K R, Bhatta N K, Niraula S R, Gurung, R, Pokharel, P K. A measure of transmission of Tuberculosis Infection among children in household contact. SAARC Journal of Tuberculosis, Lung Diseases and HIV/AIDS. Vol. XVI, No. 1,2018: 25-32.

20. Anderson JG. Health Services Utilization: Framework and Review. Health Serv Res. 1973 Fall; 8(3): 184-199

21. Taksande AM, Yeole M. Risk factors of Acute Respiratory Infection (ARI) in under-fives in a rural hospital of Central India. J Pediatr Neonat Individual Med. 2016;5(1):e050105. doi: 10.7363/050105.

22. Prietsch SO, Fischer GB, César JA, Lempek BS, Barbosa LV Jr, Zogbi L. Acute lower respiratory illness in under-five children in Rio Grande, Rio Grande do Sul State, Brazil: prevalence and risk factors.Cad Saude Publica. 2008 Jun;24(6):1429-38.

23. Dhimal M, Dhakal P, Shrestha N, Baral K, Maskey M.Environmental burden of acute respiratory infection and pneumonia due to indoor smoke in Dhading.J Nepal Health Res Counc. 2010 Apr;8(1):1-4. 